\title{
Toxicity of Monosodium Glutamate on Liver and Body Weight with the Protective Effect of Tannic Acid in Adult Male Rats
}

\author{
Palkis A. Mohamed ${ }^{1}$, Sherine A. Mohammed ${ }^{2}, \operatorname{Rania}$ A. $\operatorname{Radwan}^{1}$, and Soheir A. Mohamed ${ }^{1}$.
}

\begin{tabular}{|c|c|}
\hline & ABSTRACT \\
\hline $\begin{array}{l}\text { KEYWORDS } \\
\text { Monosodium glutamate; } \\
\text { Liver toxicity, } \\
\text { Tannic acid, } \\
\text { Experimental. }\end{array}$ & $\begin{array}{l}\text { One of the food additives that are used extensively in the food industry is } \\
\text { monosodium glutamate which has a flavor enhancer that is considered a double- } \\
\text { edged sword on human health. Tannic acid (TA) is a natural antioxidant that works } \\
\text { against many toxic substances. The current study aimed to evaluate the toxicity of } \\
\text { MSG on rat liver with a possible protective role of TA. Forty adult male albino rats } \\
\text { were used. They were divided into } 4 \text { equal groups, } 10 \text { rats each. Group, I was the } \\
\text { control group, Group II received TA (100 } \mathrm{mg} / \mathrm{kg} \text { ) by oral gavage, Group III received } \\
\text { MSG ( } \mathrm{g} / \mathrm{kg} \text { ) by oral gavage and Group IV received (TA and MSG) by oral gavage } \\
\text { for } 4 \text { weeks. At the end of the study, biochemical analysis was done and revealed that } \\
\text { Group III showed a significant increase in the body weight and significant elevation } \\
\text { in the serum levels of ALT and AST enzymes compared to group I with p }>0.001 \text {. } \\
\text { While, there was a non-significant difference in relative liver weight with p }>0.05 \text {. } \\
\text { Histopathological examination revealed that group III showed a severe complete loss } \\
\text { in hepatic architecture such as congestion and dilatation in the blood vessels with } \\
\text { different cellular changes such as necrosis and apoptosis as compared to group I. All } \\
\text { these deleterious effects of MSG were greatly ameliorated by TA administration in } \\
\text { group IV as compared to group III. }\end{array}$ \\
\hline
\end{tabular}

Introduction

Monosodium glutamate is a flavorenhancing agent which is one of the most important factors that attract people towards the food and it is used in the food industry with a characteristic umami taste. It is a nonessential amino- acids found abundant in nature (Zanfirescu et al., 2019).

\footnotetext{
${ }^{(l)}$ Forensic Medicine \& Clinical Toxicology Department, Faculty of Medicine, Suhag University, Suhag, Egypt.

${ }^{(2)}$ Histology Department, Faculty of Medicine, Sohag University, Sohag, Egypt.
}

The safety and toxicity of MSG had become controversial in the last few years because MSG has some harmful effect on the human and animal tissues through induction of oxidative stress in different body organs (Husarova and Ostatnikova, 2013; HenryUnaeze, 2017).

The liver plays a major role in metabolic activities which involve synthesis, biotransformation, and storage of numerous substances, so it is one of the most affected organs by toxic substances such as MSG (Kazmi et al., 2017). 
Tannic acid (TA) is a potent antioxidant that increases the antioxidant enzymes and it plays a protective role against oxidative stress through having highly effective ferric reducing and scavenging free radical power and it acts as electron donors (Babby et al., 2019).

The present study aimed to evaluate the toxicity of MSG on rat liver with the possible protective role of TA.

\section{Materials \& Methods:}

\section{Chemicals}

1- Monosodium glutamate (MSG) powder and tannic acid (TA) powder were purchased from Sigma Aldrich Company, Germany.

2- Kits of alanine aminotransferase (ALT) and kits of aspartate aminotransferase (AST) were purchased from Beckman Coulter Inc. Company, USA.

\section{Animals}

Forty healthy adult white albino male rats were used. They were 7 weeks old and weighed $(200 \pm 20 \mathrm{~g})$. Animals were purchased from the Animal Facility Center of the Faculty of Medicine Helwan University. The animals were housed in the animal house, under ambient temperature and they were kept under fixed appropriate humidity and light conditions. They were acclimatized to the laboratory condition for one week before starting the treatment protocol. Animals were fed with standard pellet food and water. The protocol was approved by the local ethical committee of the Faculty of Medicine, Sohag University.

\section{Experimental design}

At the end of the adaptation period, the rats were weighed and divided randomly into 4 groups, 10 rats each.
Group I (control): The animals received water and diet orally for 4weeks. Group II (TA): The animals received daily $100 \mathrm{mg} / \mathrm{kg}$ of TA by oral gavage for 4weeks (Hassan et al., 2011).

Group III (MSG): The animals received daily $2 \mathrm{~g} / \mathrm{kg}$ of MSG which represents $1 / 7$ of oral $\mathrm{LD}_{50}$ by oral gavage for 4weeks (Calis et al., 2016; Sayed et al., 2016).

Group IV (MSG +TA): The animals received both TA $(100 \mathrm{mg} / \mathrm{kg})$ and MSG (2 $\mathrm{g} / \mathrm{kg})$ by oral gavage for 4 weeks.

After completing the study period, the experimental rats were weighed then blood and tissue samples were collected immediately after they were sacrificed.

\section{Methods}

\section{Body weights and Relative Liver Weights}

The body weight of each animal was determined before treatments and before sacrifice. The liver of each rat was washed with normal saline, dried between blotting paper, and then weighed. The value of each was assumed as $100 \%$ relative liver weight (RLW) was calculated according to the formula previously described by (Ashafa et al., 2012).

$$
\mathrm{R} L W=\frac{\text { liver weight }}{\text { Body weight }} \times \mathbf{1 0 0}
$$

\section{Sample collection and storage}

The blood samples $(3 \mathrm{ml})$ were taken from retro-orbital blood vessels, collected in centrifuge tubes, centrifuged at $4000 \mathrm{rpm}$ for 15 min then serum was immediately stored at $-20^{\circ} \mathrm{C}$ until their use for assessment of liver enzymes. Then the animals were dissected to 
expose the liver organ for histopathological examination.

\section{Biochemical analysis}

The liver enzymes: Serum alanine transaminase (ALT) and aspartate transaminase (AST) levels were estimated by using enzyme-linked immunosorbent assay by spectrophotometry apparatus (Beckman Coulter AU480).

\section{Histopathological analysis}

Slices from the liver tissues were fixed in $10 \%$ neutral formalin. Liver tissues were processed and prepared for serial paraffin section of $5 \mu \mathrm{m}$ thickness examination for histopathological examination by Light microscopy.

\section{Statistical analysis}

Statistical Package for Social Science (IBM-SPSS), version 24 (May 2016); IBM, Chicago, USA was used for statistical data analysis. The data were expressed as mean \pm standard deviation (SD), number, and percentage. Mean and standard deviation was used as a descriptive value for quantitative data. The Student's t-test was used to compare the means between two groups, and a One Way analysis of variants (ANOVA) test was used to compare means of more than two groups.

\section{Results:}

Regarding the body weights, table (1) showed a significant difference in both initial body weight (IBW) and final body weight (FBW) with weight gain (WG) in the studied groups as compared to the control group with $\mathrm{p}<0.001$.

The animals treated with MSG (Group III) showed a very highly significant statistical increase in the FBW where the WG was $32.70 \%$ as compared to the control group (Group I) where the WG was $10.7 \%$ With $\mathrm{p}<0.001$. While there was a highly significant statistical reduction in FBW in group IV that was treated with TA where the WG was $10.52 \%$ as compared to group III where the WG was $32.70 \%$ with $\mathrm{p}<0.01$.

Table (1): Mean value and \pm SD of body weight (initial, final and weight gain ratio) in the studied groups $(n=40)$.

\begin{tabular}{|c|c|c|c|c|c|c|c|c|c|}
\hline \multirow[b]{3}{*}{ Variables } & \multicolumn{4}{|c|}{ Mean ( \pm SD) } & \multicolumn{5}{|c|}{ p-value } \\
\hline & \multirow[b]{2}{*}{ I } & \multirow[b]{2}{*}{ II } & \multirow[b]{2}{*}{ III } & \multirow[b]{2}{*}{ IV } & \multicolumn{4}{|c|}{ t-test } & \multirow[b]{2}{*}{ ANOVA } \\
\hline & & & & & $\begin{array}{c}\text { II } \\
\text { versus } \\
\text { I }\end{array}$ & $\begin{array}{c}\text { III } \\
\text { versus } \\
\text { I }\end{array}$ & $\begin{array}{c}\text { IV } \\
\text { versus } \\
\text { I }\end{array}$ & $\begin{array}{c}\text { III } \\
\text { versus } \\
\text { IV }\end{array}$ & \\
\hline IBW(g) & $\begin{array}{c}193.30 \\
\pm \\
9.60\end{array}$ & $\begin{array}{c}217 \\
\pm \\
11.59 \\
\end{array}$ & $\begin{array}{c}204 \\
\pm \\
5.16 \\
\end{array}$ & $\begin{array}{c}209 \\
\pm \\
11.0 \\
\end{array}$ & $0.000 *$ & 0.018* & $0.001 *$ & 0.255 & $0.000 *$ \\
\hline FBW(g) & $\begin{array}{c}214 \\
\pm \\
13.49 \\
\end{array}$ & $\begin{array}{c}238 \\
\pm \\
13.16 \\
\end{array}$ & $\begin{array}{c}270.5 \\
\pm \\
20.33 \\
\end{array}$ & $\begin{array}{c}231 \\
\pm \\
23.89 \\
\end{array}$ & $0.006 *$ & $0.000 *$ & $0.045 *$ & $0.000 *$ & $0.000 *$ \\
\hline WG \% & 10.7 & 9.67 & 32.70 & 10.52 & 0.811 & $0.000 *$ & 0.910 & $0.000 *$ & $0.000 *$ \\
\hline
\end{tabular}

* p < 0.05: Significant, SD: Standard deviation, \%: Percentage, IBW: Initial body weight, FBW: Final body weight, WG: Weight gain, N; Number, Group I: Control group, Group II: Rats treated by TA, Group III: Rats treated by MSG, Group IV: Rats treated by (TA+MSG). 
As regards, the relative liver weight (RLW), table (2) shows no significant difference in studied groups as compared to the control group with $\mathrm{p}>0.05$ and MSG had a non-significant effect on the liver weight in group III when compared to group I with $\mathrm{p}>$ 0.05 .

Table (2): Mean value and \pm SD of relative liver weight in the studied groups $(n=40)$

\begin{tabular}{|c|c|c|c|c|c|c|c|c|c|}
\hline \multirow[b]{3}{*}{ Variables } & \multicolumn{4}{|c|}{ Mean $( \pm$ SD) } & \multirow{2}{*}{\multicolumn{4}{|c|}{$\frac{\text { p value }}{\text { t-test }}$}} & \multirow[b]{3}{*}{ ANOVA } \\
\hline & \multirow[b]{2}{*}{ I } & \multirow[b]{2}{*}{ II } & \multirow[b]{2}{*}{ III } & \multirow[b]{2}{*}{ IV } & & & & & \\
\hline & & & & & $\begin{array}{c}\text { II } \\
\text { versus } \\
\text { I }\end{array}$ & $\begin{array}{c}\text { III } \\
\text { versus } \\
\text { I }\end{array}$ & $\begin{array}{c}\text { IV } \\
\text { versus } \\
\text { I }\end{array}$ & $\begin{array}{c}\text { III } \\
\text { Versus } \\
\text { IV }\end{array}$ & \\
\hline RLW & $\begin{array}{c}3.76 \\
\pm \\
0.81 \\
\end{array}$ & $\begin{array}{c}3.44 \\
\pm \\
0.42 \\
\end{array}$ & $\begin{array}{c}4.15 \\
\pm \\
.032 \\
\end{array}$ & $\begin{array}{c}3.70 \\
\pm \\
0.68\end{array}$ & 0.237 & 0.152 & 0.823 & 0.1 & 0.082 \\
\hline
\end{tabular}

SD: Standard deviation, RLW: Relative liver weight, (ANOVA): One-Way Analysis of Variance, group I: Control group, group II: Rats treated by TA, group III: Rats treated by MSG, group IV: Rats treated by (TA+MSG).

The biomarkers of liver function (AST and ALT) in table (3) showed a significant rise in their serum level in the studied groups with $\mathrm{p}<0.001$. Comparing MSG treated group to the control group, revealed a very highly significant statistical increase in both liver enzymes (ALT and AST) level which returned to normal levels when they were treated with the anti-oxidant TA (Group IV) rather than those treated with MSG only with $\mathrm{p}<0.001$.

Table (3): Mean value ( \pm SD) of liver function tests between the studied groups $(n=40)$.

\begin{tabular}{|c|c|c|c|c|c|c|c|c|c|}
\hline \multirow{3}{*}{ Variables } & \multicolumn{4}{|c|}{ Mean ( \pm SD) } & \multicolumn{5}{|c|}{ p-value } \\
\hline & \multirow[b]{2}{*}{ I } & \multirow[b]{2}{*}{ II } & \multirow[b]{2}{*}{ III } & \multirow[b]{2}{*}{ IV } & \multicolumn{4}{|c|}{ t-test } & \multirow[b]{2}{*}{ ANOVA } \\
\hline & & & & & $\begin{array}{c}\text { II } \\
\text { versus I }\end{array}$ & $\begin{array}{c}\text { III versus } \\
\text { I }\end{array}$ & $\begin{array}{c}\text { IV versus } \\
\text { I }\end{array}$ & $\begin{array}{c}\text { III } \\
\text { Versus IV }\end{array}$ & \\
\hline $\begin{array}{c}\text { Serum ALT } \\
(\mathrm{U} / \mathrm{L})\end{array}$ & $\begin{array}{c}39.27 \pm \\
3.64\end{array}$ & $\begin{array}{c}38.03 \pm \\
4.1\end{array}$ & $\begin{array}{l}62.1 \pm \\
10.33\end{array}$ & $\begin{array}{c}48.8 \pm \\
5.77\end{array}$ & 0.540 & $0.000 *$ & $0.003 *$ & 0.008* & $0.000 *$ \\
\hline $\begin{array}{c}\text { Serum AST } \\
(\mathrm{U} / \mathrm{L})\end{array}$ & $\begin{array}{c}145.4 \pm \\
24.4\end{array}$ & $\begin{array}{c}163.3 \pm \\
26.4\end{array}$ & $\begin{array}{c}254.7 \pm \\
32.5\end{array}$ & $\begin{array}{c}213.7 \pm \\
14.59\end{array}$ & 0.187 & $0.000 *$ & $0.000 *$ & $0.007 *$ & $0.000 *$ \\
\hline
\end{tabular}

*Significant, ALT: Alanine aminotransferase, AST: Aspartate aminotransferase, group I: Control group, group

II: Rats treated by TA, group III: Rats treated by MSG, group IV: Rats treated by (TA+MSG)

\section{Histopathological results}

The histopathological examination of group II (Figure 1B) didn't show significant difference with group I (Figure 1A). While the effect of MSG was markedly declared on group III (Figure 1C) where there was severe damage in the hepatic tissues such as congestion and dilatation of blood vessels with different cellular change including; necrosis, apoptosis, polymorphism and prominent Kupffer cells as compared to groups $\mathrm{I}$ and II (Figure 1A \& 1B). Meanwhile, administration of TA in rats showed improvement in the hepatic architecture with less or normal of its cellular components (Figure 1D) as compared to MSG treated group (Figure 1C). 


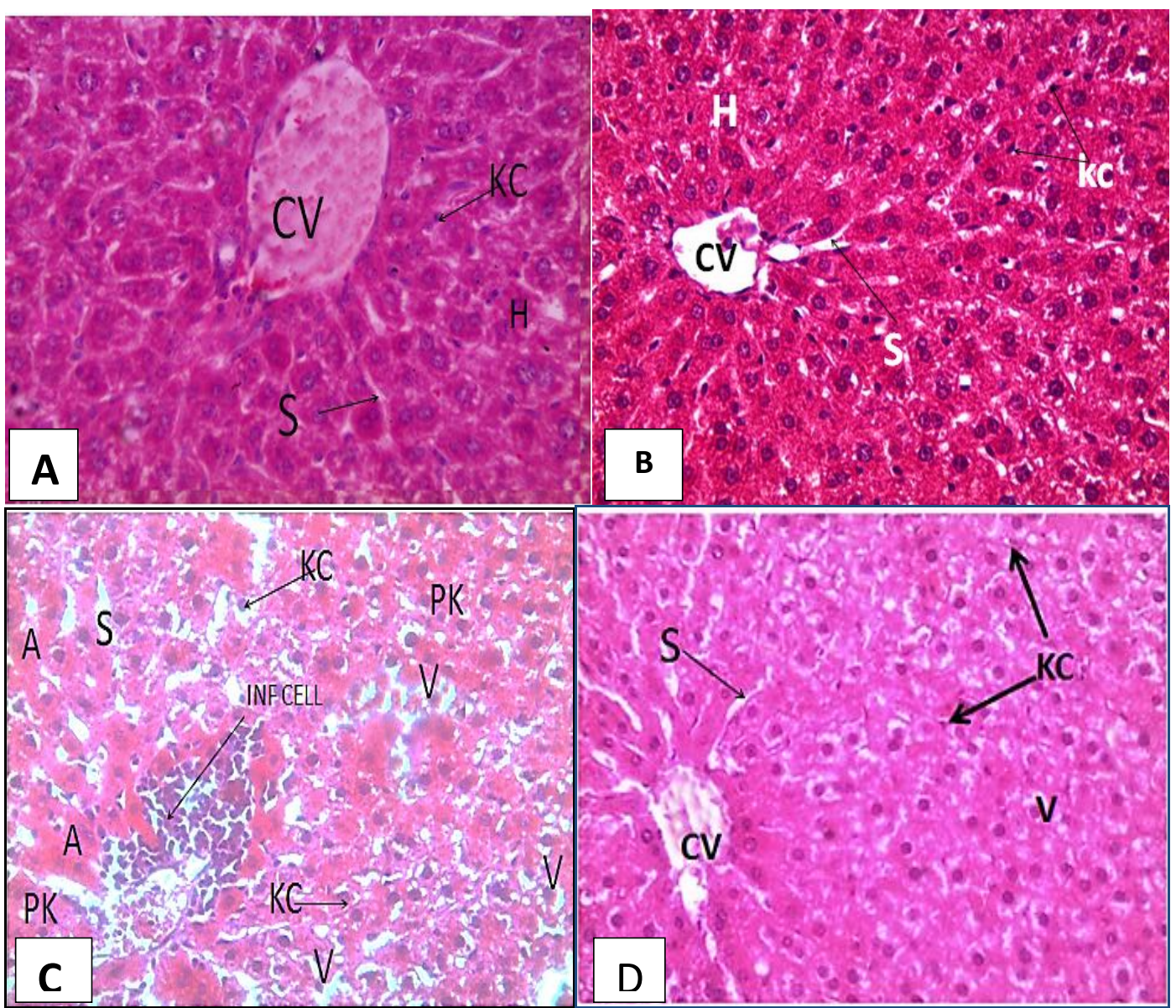

Fig.(1): A photomicrograph of a liver section(A) and (B) with H\&E stained from the control group (I) and TA treated group (II) respectively showing normal hepatic architecture with the normal central vein (CV), Normal hepatocytes (H) and kupffer cells (KC) with normal blood sinusoids (s) between the hepatic plates. Liver section (C) from MSG treated group (III) showing complete disturbance in hepatic architecture with different cellular changes; vacuolated cytoplasm (V) and highly acidophilic cytoplasm (A), pyknosis (PK), Prominent Kupffer (KC) cells and dilated blood sinusoids (S). A Photomicrograph of liver section (D) from TA and MSG treated group (IV) showing improvement in hepatic architecture. The hepatocytes are more or less normal with milder vacuolated cytoplasm (V) and less prominent kupffer cells $(\mathrm{KC})$ with normal blood sinusoids $(\mathrm{S})$ in between.

\section{Discussion:}

Nowadays, there is a great tendency towards the usage of processed food containing many food additives such as MSG which is considered a double-edged sword on human health (Henry-Unaeze, 2017).

The present study revealed that MSG affects the body weight in a positive manner where the weights of rats were significantly heavier in group III when compared to group I.
The mechanism of MSG-induced obesity is not quite clear. MSG might be neurotoxic through induction of neuronal necrosis via damage in the hypothalamic arcuate nucleus (ARC) or by an increase in energy intake (Bautista et al., 2019).

The current study was in harmony with (Kumbhare et al., 2015) and Ahmed (2016) who revealed a significant increase in body weight in MSG- treated rats as compared to non -treated group. 
MSG didn't induce any significant difference in the mean value of relative liver weight (RLW) when compared to control group which was supported by the Ibegbulem et al. (2016).

On contrary, Nagata et al.(2006); Sasaki et al. (2009) and Tawfik and Al-Badr (2012) reported that RLW significantly increased in MSG treated group compared to the control group.

The present results revealed that TA could control the body weight in group IV as compared to group III while no significant difference was observed in the liver weight which was in agreement with Barszc et al. (2018).

The present results showed that the serum levels of AST and ALT enzymes were significantly elevated in the MSG treated group as compared to the control group.

The degree of hepatic toxicity induced by MSG could be detected by measuring the serum level of hepatic enzymes (AST \& ALT) which are released into the circulation from the necrotic membrane of hepatocytes (Ahmed et al, 2019).

This could be explained by the oxidative stress and free radicals production that reacts with polyunsaturated fatty acids of the cell membrane leading to disturbance in the mitochondrial and plasma membranes function resulting in enzymatic release (Okediran et al., 2014; Ahmed et al., 2019).

The current study was following many researchers many researchers who recorded elevation in the AST and ALT enzyme levels as a result of MSG administration. Some investigators used single high doses as Ortiz et al. (2006), Soliman (2011) and Okediran et al. (2014). While other investigators as Onyema et al. (2006); Egbuonu et al. (2009) and Abd-Ella et al. (2016) used small doses.

Moreover, combined administration of TA with MSG in the current study was effective in improving liver function through significant reduction in the levels of ALT and AST enzymes which might reflect the inhibitory effect of TA on MSG inducedhepatotoxicity.

The present study was in agreement with many researchers who showed the ameliorative effect of TA on different toxins induced liver damage which resulted in significant recovery of hepatic aminotransferase activities such as Omar et al. (2003) who used TA to improve the aluminium - induced hepatic toxicity also, Sehrawat et al. (2006) studied the preventive effect of TA on acetyl amino fluorine (2AAF) similarly, El-Sayed et al. (2006) studied the protective role of TA on lead poisoning.

The current results showed severe destruction in the hepatic architecture in MSG treated group such as vacuolar degeneration, pyknosis and necrosis in the hepatocytes in addition to congestion and dilatation in the blood sinusoid when compared to the control group.

These findings were in accordance to Eweka et al. (2011) and AL-Mosaibih (2013) who revealed disruption in the liver architecture with different cellular necrotic changes in MSG treated group compared to the control group while administration of TA with MSG restored the alterations in the degree of liver toxicity towards the normal levels.

The TA was found to be an effective natural antioxidant that has different antioxidant activities when compared to other antioxidants such as BHA, BHT, a-tocopherol and Trolox as references antioxidant (Glüçin et al., 2010).

The current results were in agreement with Omar et al. (2003); Jianping et al. (2017); Basu et al. (2018) and Alechinsky et al. (2020) who used TA to protect the liver against different toxins. 
On contrary to the current results; Calis et al. (2016) reported that combined TA with MSG administration in group IV didn't cause significant histological changes in the liver due to short duration (7days).

\section{Conclusion}

Oral consumption of MSG with large dosage resulted in varying degrees of liver injury and TA played an important role in the protection and improvement of liver against (MSG) toxicity.

\section{Acknowledgement}

The authors would like to express their deepest thanks and gratitude to all staff members of the Forensic Medicine and Clinical Toxicology and Histology Departments, Sohag University for their contribution in this study.

\section{Conflict of interest:}

The authors had no conflict of interest to be cleared.

\section{References:}

Abd-Ella, E.M.M. and Mohamme, A.M. A. (2016) Attenuation of monosodium glutamate-induced hepatic and testicular toxicity in albino rats by Annona muricata Linn. (Annonaceae) leaf extract', IOSR Journal of Pharmacy and Biological Sciences, 11 (6), p61-69.

Ahmed, M.M.H, (2016) 'Effect of some food additives consumption on the body weight and toxicity and the possible ameliorative role of green tea extract', Middle East Journal of Applied Sciences, (6) 4, p716-730.
Ahmed, R.R.; Abdul-Hamid, M.; Galal, S.R. and Hamdalla, H.M. (2019) Monosodium glutamate-induced liver microscopic and bio-chemical changes in male rats and the possible amendment of quercetin', Egyptian Journal of Zoology, 71, p44-55.

AL-Mosaibih, M.A. (2013) 'Effects of monosodium glutamate and acrylamide on the liver tissue of adult Wister rats', Life Science Journal, 10 (2), p35-42.

Alechinsky, L.; Favreau, F.; Cechova, P.; et al. (2020) "Tannic acid improves renal function recovery after renal warm ischemia-reperfusion in a rat model', Biomolecules, 439 (10), p1-16.

Ashafa, A.T.O.; Orekoya, L.O. Yakubu, M.T. (2012) 'Toxicity profile of ethanolic extract of Azadirachta indica stem bark in male Wister rats', Asian Pacific Journal of Tropical Biomedicine, 2 (10), p811-817.

Babby, A.; Elanchezhiyan, C.; Hassan, T. and Naseer, I. (2019) Effect of tannic acid on lipid peroxidation and antioxidants status in streptozotocininduced diabetic rats', International Journal of Recent Scientific Research, 10 (05), p32591-32594.

Barszc, M.; Taciak, M.; Tuśnio, A. and Skomial, J. (2018) "Effects of dietary level of tannic acid and protein on internal organ weights andbiochemical blood parameters of rats', PLOS ONE, 13(1),

https://doi.org/10.1371/journal.pone.019 0769.

Basu, T.; Panja, S.; Shendge, A.K.; et al. (2018) 'A natural antioxidant, tannic acid mitigates iron-overload induced hepato-toxicity in Swiss albino mice through ROS regulation', Environmental Toxicology, 33(5), p603-618. 
Bautista, R.J.H.; Mahmoud, A.M.; Königsberga, $M$. and Guerrero, N.E.L.D. (2019) 'Obesity: Pathophysiology, monosodium-glutamate induced model and anti-obesity medicinal plants', Biomedicine \& Pharmacotherapy, 111, p503-516.

Calis, I.U.; Cosan, D.T.; Saydam, F.; et al. (2016) 'The effects of monosodium glutamate and tannic acid on adult rats', Iran Red Crescent Med. J., 18(10), p1-7.

Egbuonu, A.C; Obidoa, O; Ezeokonkwo, C.A; et al. (2009) 'Hepatotoxic effects of low dose oral administration of monosodium glutamate in male albino rats', Afr. J. Biotech., 8, p3031-3035.

El-Sayed, I.H.; Lotfy, M.; El-Khawaja, et al. (2006) 'Prominent free radicals scavenging activity of tannic acid in lead-induced oxidative stress in experimental mice', Toxicology and Industrial Health, 22, p157 -163.

Eweka, A.O.; Igbigbi, P.S. and Ucheya, R.E. (2011) "Histochemical Studies of the effects of monosodium glutamate on the liver of adult Wister rats', Annals of Medical and Health Sciences Research - January, 1(1), p21-30.

Glüçin, I.; Huyut, Z.; Elmastas, M. and Aboul-Enein, H.Y. (2010) 'Radical scavenging and antioxidant activity of tannic acid', Arabian Journal of Chemistry, 3, p43-53.

Hassan, A.M.; Sekena, H.; Abd El-Aziem, S.H.; et al. (2011) 'Antimutagenic effects of tannic acid on somatic and germ cells of rat', Egypt. J. Genet. Cytol., 40, p15-29.

Henry-Unaeze, H.N. (2017) "Update on food safety of monosodium 1 glutamate (MSG)', Pathophysiology, 24:p243249.
Husarova, V. and Ostatnikova, D. (2013) Monosodium glutamate toxic effects and their implications for human intake: A Review', JMED Research., p1-12, DOI: $10.5171 / 2013.608765$.

Ibegbulem, C.O.; Chikezie, P.C.; Ukoha, A.I. and Opara, C.N. (2016) 'Effects of diet containing monosodium glutamate on organ weights, acute blood steroidal sex hormone levels, lipid profile and erythrocyte antioxidant enzymes activities of rats', Journal of Acute Disease, 5(5), p402-407.

Jianping, Z.; Qiongtao, S.; Xue, H.; et al. (2017) "Multi-targeted protection of acetaminophen-induced hepatotoxicity in mice by tannic acid', International Immune Pharmacology, 47, p95-105.

Kazmi, Z.; Fatima, I.; Perveen. S. and Malik, S.S. (2017) 'Monosodium glutamate: Review on clinical reports', International Journal of Food Properties; 20 (2), p1807-1815.

Kumbhare, V.; Gajbe, U.; Singh, B.R.; et al. (2015) 'Histological \& histochmical changes in the liver of adult rats treated with monosodium glutamate: a light microscopic study', World Journal of Pharmacy and Pharmaceutical Sciences, 4(4), p898-911.

Nagata, M.; Suzuki,W.; Iizuka, S.; et al. (2006) Type 2 diabetes mellitus in obese mouse model induced by monosodium glutamate', Exp. Anim., 55 (2), p109115 .

Okediran, B.S.; Olurotimi, A.E.; Rahman, S.A.; et al. (2014) "Alterations in the lipid profile and liver enzymes of rats treated with monosodium glutamate', Sokoto Journal of Veterinary Sciences, 12 (3), p42-46.

Omar, H.M.; Hassan, K.A.; Abd-Elghaffar, S.K.H. and Ahmed, E.A. (2003) 'Aluminium toxicity in rats: The role of 
tannic acid as antioxidant', Ass. Univ. Bull. Environ. Res., 6 (2), p1-14.

Onyema, O.O.; Farmobi, E.O.; Emerole, G.O.; et al. (2006) "Effect of vitamin E on monosodium glutamate induced hepatotoxicity and oxidative stress in rats', Journal of Biochemistry \& Biophysics Indian, 43 (1), p20-24.

Ortiz, G.G; Bitzer-Quintero, O.K.; BeasZárate, C.S.; et al. (2006) Monosodium glutamate induced damage in liver and kidney: a morphological and biochemical approach', Biomedicine \& Pharmacotherapy, 60, p 86-91.

Sasaki, Y.; Suzuki, W.; Shimada, T.; et al. (2009) 'Dose-dependent development of diabetes mellitus and non-alcoholic steatohepatitis in monosodium glutamate-induced obese mice', Life Sciences, 85, p490-498.

Sehrawat, A.; Sharma, S. and Sultana, S. (2006) Preventive effect of tannic acid on 2-acetylaminofluorene induced antioxidant level, tumor promotion and hepatotoxicity: A chemo-preventive study', Redox Report, 11(2), p85-95.

Soliman, A.M. (2011) Extract of coelaturaaegyptiaca, a freshwater clam, ameliorates hepatic oxidative stress induced by monosodium glutamate in rats', African Journal of Pharmacy and Pharmacology, 5 (3), p398-408.

Tawfik, M.S. and Al-Badr, N. (2012) Adverse effects of monosodium glutamate on liver and kidney functions in adult rats and potential protective effect of vitamins C and E', Food and Nutrition Sciences, 3, p651-659.

Zanfirescu, A.; Ungurean, A.; Tsatsakis, A.M.; et al. (2019) 'A Review of the alleged health hazards of monosodium glutamate', Comprehensive Reviews in Food Science and Food Safety, 18, p1111-1133. 


\title{
سمية الجلوتاميت احادي الصوديوم علي الكبد ووزن الجسم مع التاثير الوقائي لحمض التانيك علي

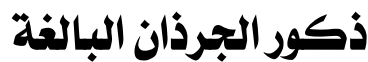

\author{
'بلقيس احمد محمد، 'رانيا احمل رضوان ، 'شرين احمد محمد و 'سهير علي محمد \\ ' قسم الطب الثرعى و السموم الاكلينيكية، كلية الطب،جامعة سوهاج

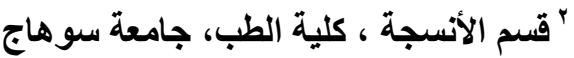

يعد الجلوتاميت أحادي الصوديوم من احد مكسبات الطعم التي تستخدم على نطاق واسع في صنامي صناعة

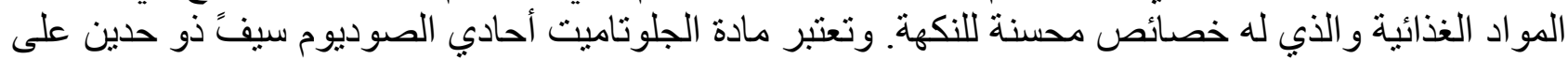

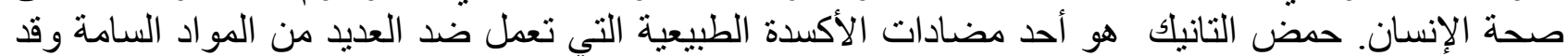

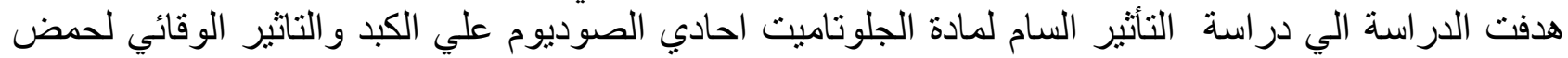

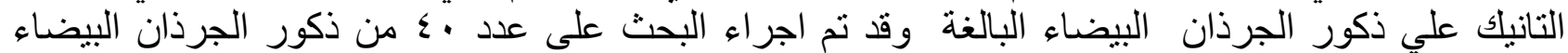

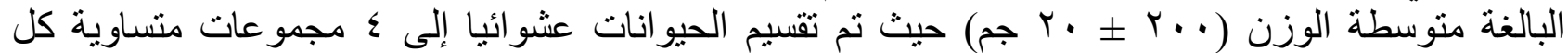

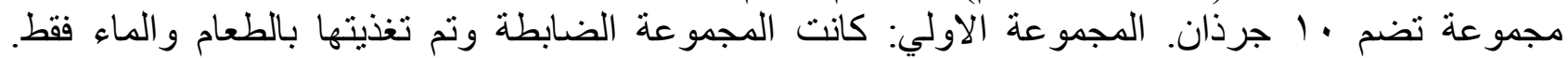

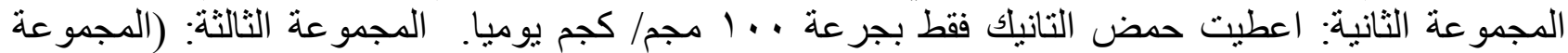

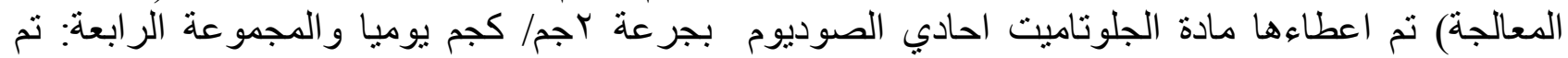

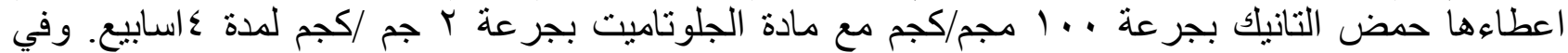

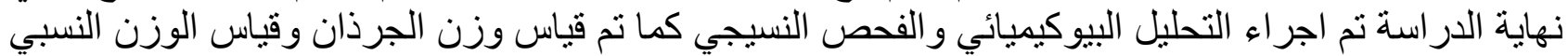

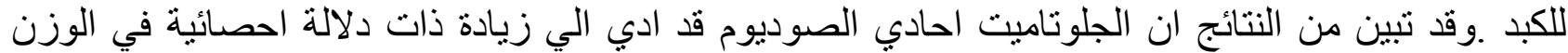

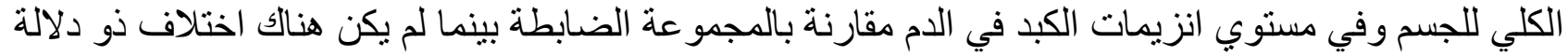

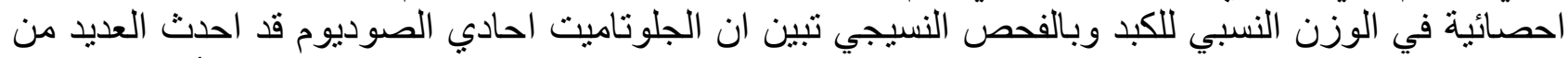

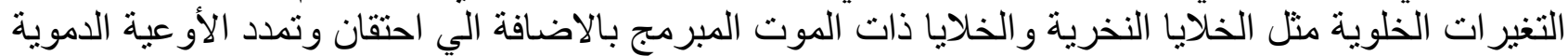

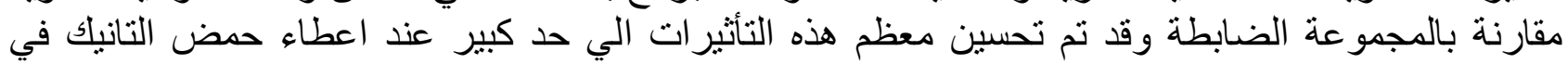

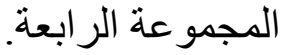

